\title{
The Influence of Service Quality to the Customer Satisfaction and Revisit Interest of Saporkren Ecotourism at Raja Ampat Regency
}

\author{
Robinsar Jogi Yoshua Manullang ${ }^{1}$, Siti Jahroh ${ }^{1} \&$ Kirbrandoko $^{1}$ \\ ${ }^{1}$ School of Business, IPB University, Bogor, Indonesia \\ Correspondence: Robinsar Jogi Yoshua Manullang, School of Business, IPB University, Bogor, West Java, \\ Indonesia. E-mail: jogijoshua@gmail.com
}

Received: August 6, 2020

doi:10.5539/ijbm.v16n2p21
Accepted: December 21, 2020

Online Published: January 9, 2021

URL: https://doi.org/10.5539/ijbm.v16n2p21

\begin{abstract}
Ecotourism is a nature tourism that focuses on a protected area or area that contributes to the welfare of the local community and conservation and education for the community. Meanwhile, as much as 98.9 percent of the forest area under its management rights is still controlled by corporations and capital owners. While the rest which is no more than 1.1 percent of the area of forest management rights is controlled by the community. Enhancing the role of forest areas, especially conservation forests, needs to be done to improve the quality of life of communities around the buffer zones. The purpose of this study is to identify service quality factors that influence customer satisfaction and interest in ecotourism visits in Saporkren, and formulate ecotourism marketing strategies in Saporkren. This is done to increase the number of ecotourism visitors in Saporkren, which of course will provide increased income for the community and improve the quality of life of the Saporkren people.

The population in this study were visitors from the Saporkren ecotourism. The sampling technique uses accidental sampling and purposive sampling. The selected respondents were tourists who were visiting Saporkren and were found by researchers and tourists who had visited Saporkren at least once in the past one year. Endogenous variables $(\mathrm{Y})$ and $(\mathrm{Z})$ in this study are consumer satisfaction and interest in return visits. Exogenous variables $(\mathrm{X})$ in this study are tangibles, reliability, responsiveness, assurance, and empathy. The data processing technique used in this study is Structural Equation Modeling (SEM) with LISREL 8.7 software.

Based on the results of the study, only three out of five service quality factors were identified that affected customer satisfaction, namely tangible, reliability, and assurance. And in this study, consumer satisfaction is proven to affect the interest in a repeat visit. After that, from the interviews and Focus Group Discussion (FGD), a strategy that could be implemented in ecotourism in Saporkren was formulated to explore potential tourism that could be exploited in addition to birdwatching for tangibles, and to train and certify tour guides in Saporkren for reliability and assurance.
\end{abstract}

Keywords: tangibles, reliability, responsiveness, assurance, emphaty, satisfaction, interest of tourists revisit

\section{Introduction}

\subsection{Introduce the Problem}

Wiratno (2012) stated that the concept of development in third world countries (including Indonesia) has been trapped in mere physical development, with the main focus of economic growth. This strategy cannot improve the welfare and quality of human life. Economists tend to separate the economy from the ecological structure that surrounds it. This condition can be seen from the lack of forest benefits felt by the community, as of 2014, as many as 98.9 percent of the area of forest management rights was still controlled by corporations and capital owners. While the rest which is no more than 1.1 percent of the area of forest management rights is controlled by the community.

Yeblo et al (2015) stated that ecotourism is a nature tourism that focuses on a protected area or area that contributes to the welfare of local communities and conservation and education for the community. Ecotourism as the organization of responsible tourism activities in natural places and / or areas created based on natural rules and economically sustainable that supports efforts to preserve the environment (natural and cultural) and improve the welfare of the local community. Conservation of natural resources is an effort to preserve nature, so 
that humans and other living things can live in harmony. Over time, the population has increased and the obsession with unlimited economic growth has made conservation activities increasingly difficult. One of the possible media in terms of conservation activities is ecotourism. Ecotourism is a concept that embraces tourism activities with conservation and is also widely understood as tourism with environmental insight.

In Indonesia, the largest conservation forest area is located in Papua, which consists of Papua and West Papua Province. Raja Ampat Regency as part of West Papua Province is one of the leading tourist destinations in Indonesia, even Raja Ampat entered as one of 18 leading tourist destinations that are sold in the Visit Wonderful Indonesia 2018 by the Ministry of Tourism. The panoramic beauty of the islands and the seabed is one of the best dive sites in the world. Not only the waters, Raja Ampat also has the potential for wealth on the mainland is no less interesting, especially the unique culture and biodiversity. However, in Raja Ampat the potential wealth on land is constrained because $43 \%$ of the land area is a conservation area. Raja Ampat Regency has a land area of 935,719 ha, and 401,337 ha of which are conservation areas. Community access is limited to conservation areas and the lack of terrestrial ecotourism in Raja Ampat has made the community still not feel the economic benefits of the forests around their homes.

The West Papua Natural Resources Conservation Agency, which has the responsibility to manage conservation areas in West Papua Province, can help the community to get environmental benefits from the conservation area. One of the things to do is to develop a terrestrial ecotourism area in Saporkren, which manage by the Saporkren Forest Farmer Group. This is done so that people no longer carry out illegal activities in the forest and get benefit from the forests around their homes.

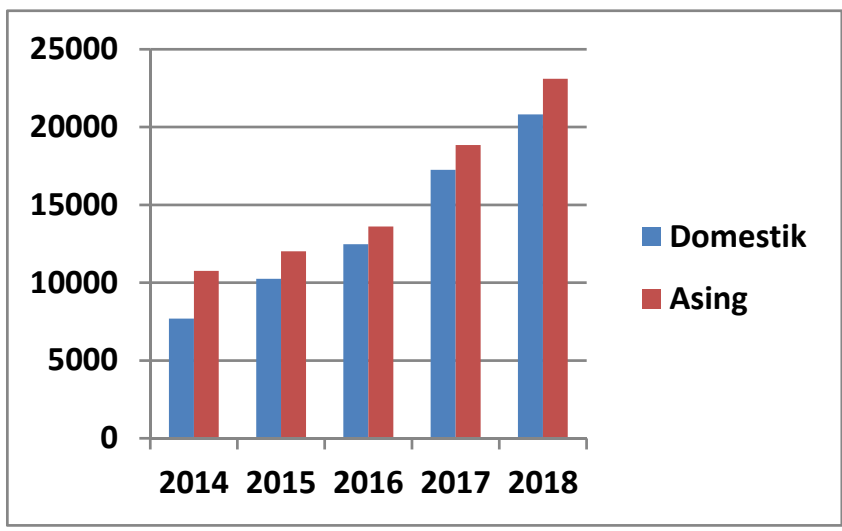

Figure 1. Data on the visit of domestic and foreign tourists to Raja Ampat Regency, West Papua Province in 2014-2018

From Figure 1 it can be seen that the number of domestic and foreign tourists is increasing every year, namely 18,450 visitors in 2014 to 43,910 visitors in 2018. Data obtained from the Central Statistics Agency of Raja Ampat in 2019. The number of visitors coming to Raja Ampat is still dominated by overseas visitors compared to domestic visitors.

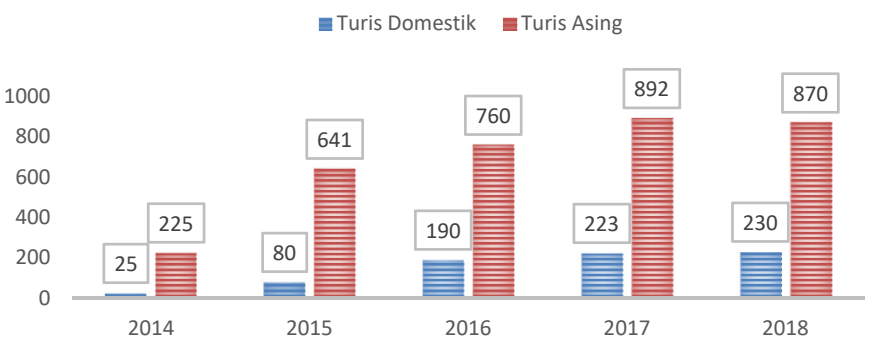

Figure 2. Data on bird watching tourist visits in Saporkren Village, Raja Ampat Regency in 2014-2018 
From Figure 2 it can be seen that the number of domestic and foreign tourists visiting Saporkren from 2014 to 2018, the most visitors occurred in 2017 with 1,115 visitors or 3.08\% of visitors coming to Raja Ampat. This number is still far from expected. It is expected that the number of visitors to Saporkren can reach 10 percent of the number of visitors coming to Raja Ampat.

The number of birdwatching visitors can still be increased, because it is still below the maximum capacity by paying attention to sustainability and sustainability. Nikijuluw etal (2017) stated that on average with an area of observation of $300 \mathrm{~m} 2$, the maximum number of tourists allowed is 24 people in Saporkren per day, with the frequency of visits 60 times per year. That means, the number of visitors can still be increased again to the number of 1,440 visitors per year. To meet the remaining number of visitors expected, it can be obtained from other tourist attractions that can be developed at Saporkren.

So that the number of tourist visits increase, research needs to be done with these developed problem formulation: what are the factors of service quality that affect customer satisfaction and the revisit interest in ecotourism at Saporkren and what is the ecotourism marketing strategy in Saporkren. This research aim to answer that problem by identify service quality factors that influence customer satisfaction and revisit interest in ecotourism at Saporkren and formulating an ecotourism marketing strategy in Saporkren.

\subsection{Literature Review}

Bebko (2000) stated that service quality is generally defined as the level of difference between customer perceptions and expectations. Parasuraman et al (1988) stated that service quality is an assessment of the level and direction of the difference between customer expectations and perceived level of actual performance. They developed the SERVQUAL model to measure service quality which consists of five dimensions, namely tangibles, reliability, responsiveness, assurance, and empathy. Kotler (2002) stated that service quality is any action or activity that can be offered by one party to another party which is basically intangible and does not result in any ownership. Indicators used to measure service quality include tangibles, reliability, responsiveness, assurance, and empathy.

Kotler (2004) stated that satisfaction is a feeling of pleasure or disappointment that comes from the comparison between the perception of the results of a product with its expectations. Tjiptono (2008) stated that visitor satisfaction is the customer's response to the evaluation of the discrepancy or disconfirmation between the previous expectations and the actual performance of the product felt after usage. Assael (2007) stated that tourist satisfaction can bring several benefits, including:

1. The relationship between tourists and managers of tourist destinations in harmony

2. Give reasons for tourists to make a repeat purchase or repeat visit

3. Loyalty tourists will be formed and loyal tourists will recommend travel destinations in word of mouth to relatives and the wider community

4. Strengthening consumer behavior towards brands and increasing the likelihood that consumers will use the same brand in the future

Nuraeni (2014) stated that buying interest is an encouragement from consumers to make a purchase or encouragement from consumers to make repeat purchases. In this study, repurchase is associated with the tourism context. This can be interpreted the same as a repeat visit. When visitors re-visit, basically visitors are satisfied with the previous visit.

\section{Method}

The location of the study was conducted in Saporkren Village, South Waigeo District which is located around the West Waigeo Nature Reserve, Raja Ampat Regency which is a working area of West Papua Natural Resources Conservation Agency. The area is managed by Saporkren Forest Farmer Group under the guidance of West Papua Natural Resources Conservation Agency to become an ecotourism site. The study began from October 2019 until February 2020. The study was conducted using a qualitative approach through interviews and Focus Group Discussions (FGD) on selected respondents coming from various stakeholders (internal, external, and experts) used to compile a strategy based on service quality and quantitative with SEM analysis tools.

The population in this study is Saporkren ecotourism visitors. Criteria for respondents as a sample in this study are tourists who have visited Saporkren ecotourism at least once and aged 15-64 years. The sampling technique uses two techniques from non probability sampling, namely purposive sampling and accidental sampling. Purposive sampling is done by setting criteria where at least 1 respondent has visited Saporkren and accidental sampling is done by taking samples from Saporkren visitors met by researchers. The sample size used in this 
study is targeted at 200 respondents. According to Loehlin (1998), the minimum sample size needed to reduce bias in all types of SEM estimates is 200 .

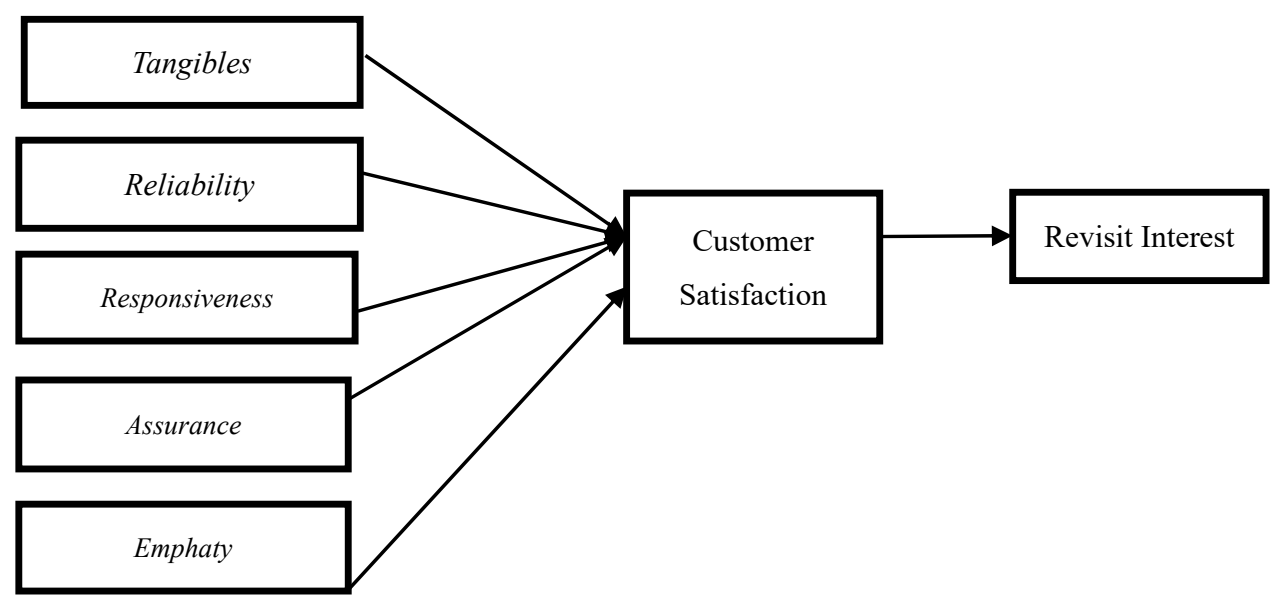

Figure 3. Conceptual Framework

H1: Tangibles has a significant effect on consumer satisfaction

H2: Reliability has a significant effect on customer satisfaction

H3: Responsiveness has a significant effect on consumer satisfaction

H4: Assurance has a significant effect on customer satisfaction

H5: Emphaty has a significant effect on customer satisfaction

H6: Consumer satisfaction has a significant effect on the revisit interest

Table 1 Variable and Indicator

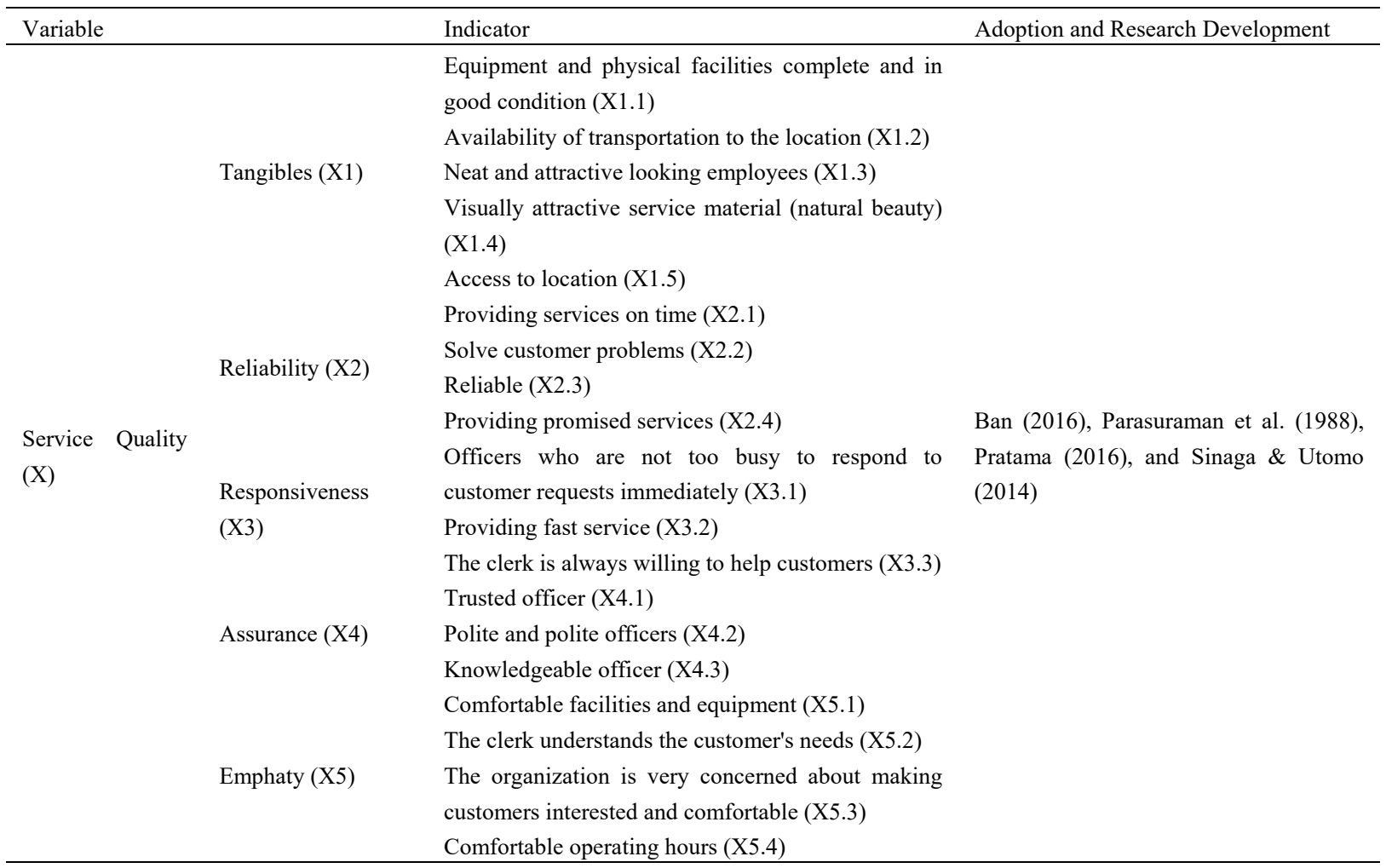




\begin{tabular}{|c|c|c|}
\hline \multirow{6}{*}{$\begin{array}{l}\text { Customer } \\
\text { Satisfaction (Y) }\end{array}$} & \multirow{7}{*}{$\begin{array}{l}\text { Customer } \\
\text { Satisfaction (Y1) }\end{array}$} & The clerk gives personal attention (X5.5) \\
\hline & & $\begin{array}{l}\text { Location and access of tourist destinations make } \\
\text { tourists satisfied (Y1.1) }\end{array}$ \\
\hline & & $\begin{array}{l}\text { The environment at the tourist site makes tourists } \\
\text { satisfied (Y1.2) }\end{array}$ \\
\hline & & All facilities at tourist sites make tourists satisfied \\
\hline & & $\begin{array}{l}\text { Existing infrastructure in Saporkren makes tourists } \\
\text { satisfied (Y1.4) }\end{array}$ \\
\hline & & $\begin{array}{l}\text { Service officers at tourist sites make tourists } \\
\text { satisfied (Y1.5) }\end{array}$ \\
\hline \multirow{5}{*}{$\begin{array}{l}\text { Revisit Interest } \\
(Z)\end{array}$} & & Overall, tourists are satisfied with Saporkren (Y1.6) \\
\hline & \multirow{4}{*}{ Revisit Interest (Z1) } & Tourists intend to make a repeat visit (Z1.1) \\
\hline & & $\begin{array}{l}\text { Tourists will make a return visit with family or } \\
\text { relatives (Z1.2) }\end{array}$ \\
\hline & & $\begin{array}{l}\text { Tourists will recommend tourist attractions to } \\
\text { family or relatives (Z1.3) }\end{array}$ \\
\hline & & $\begin{array}{l}\text { Tourists will choose Saporkren as a tourist } \\
\text { destination out of the many tourist attractions in } \\
\text { Raja Ampat (Z1.4) }\end{array}$ \\
\hline
\end{tabular}

\section{Results}

The number of respondents in this study was 238 people. Respondents are people who have visited the Saporkren ecotourism in Raja Ampat Regency. Respondent characteristics are described through demographic aspects including age, residency, recent education, and current occupation. Characteristics of respondents aim to help understand the diversity of answers from respondents. Table 3 shows the profile of respondents based on demographic aspects.

Table 2. Respondent profile

\begin{tabular}{llll}
\hline \multirow{2}{*}{ Characteristics } & Category & $\begin{array}{l}\text { Amount } \\
(\mathrm{n}=238)\end{array}$ & $\begin{array}{l}\text { Percentage } \\
(\%)\end{array}$ \\
\hline \multirow{3}{*}{ Gender } & Male & 109 & 45.80 \\
& Female & 129 & 54.20 \\
Nationality & Sorong & 31 & 13.03 \\
& Outside Sorong & 207 & 86.97 \\
& Indonesian Citizen & 206 & 86.55 \\
Education & Foreign Citizen & 32 & 13.45 \\
& High School & 61 & 25.63 \\
& Diploma & 19 & 7.98 \\
& Bachelor & 129 & 54.20 \\
& Postgraduate (S2/S3) & 29 & 12.18 \\
Occupation & Student & 19 & 7.98 \\
& Government Official & 143 & 60.08 \\
& Private employee & 39 & 16.39 \\
& State owned Enterprise employee & 3 & 1.26 \\
& Professional & 6 & 2.52 \\
& Housewife & 6 & 2.52 \\
& Entrepreneur & 13 & 5.46 \\
& Others & 9 & 3.78 \\
& $<3$ million & 45 & 18.91 \\
& $3-5$ million & 84 & 35.29 \\
& 5-10 million & 93 & 39.08 \\
& $>10$ million & 16 & 6.72 \\
\hline
\end{tabular}


In the first structural equation in this research model, Consumer satisfaction $=0.26$ (Tangibles) +0.37 (Reliability) +0.02 (Responsiveness) +0.25 (Assurance) +0.04 (Emphaty). Based on this, it is known that reliability has the greatest significant effect on customer satisfaction which is equal to 0.37 . In the second structural equation, interest in revisit $=0.72 *$ Customer satisfaction is known. This shows that consumer satisfaction has a considerable influence on the interest in a repeat visit. The standardized loading factor value in the SEM model is presented in Figure 4.

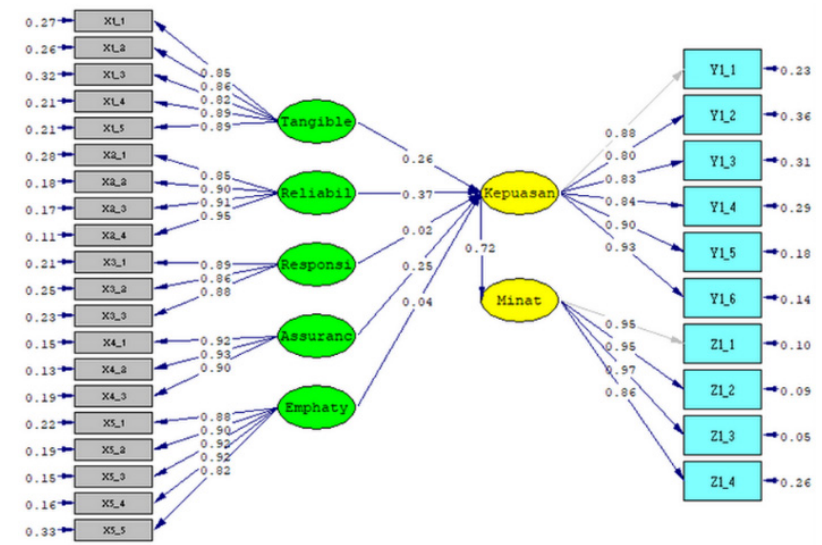

Figure 4 Standardized loading factor values in the SEM model

Note. $\left.{ }^{*}\right)$ Significant at t-count $\geqslant 1.96$.

\section{Discussion}

Testing the research hypothesis is done by analyzing the path coefficient and the calculated value of the structural model. The effect of a variable will be concluded significantly if the path coefficient value $\geqslant 0.05$ with a t-test value $\geqslant 1.96$. The diversity of factors was also assessed through the R-square model value. Hypothesis test results are presented in Table 3.

Table 3. Hypothesis test results

\begin{tabular}{llll}
\hline Influence between Variable & $\begin{array}{l}\text { Path } \\
\text { Coefficient }\end{array}$ & $\begin{array}{l}\mid \text { t-values } \mid>1 . \\
\text { Note }\end{array}$ \\
\hline Tangibles $\rightarrow$ Customer Satisfaction & 0.26 & $2.29^{*}$ & Accept H1 \\
Reliability $\rightarrow$ Customer Satisfaction & 0.37 & $2.13^{*}$ & Accept H2 \\
Responsiveness $\rightarrow$ Customer Satisfaction & 0.02 & 0.10 & Deny H3 \\
Assurance $\rightarrow$ Customer Satisfaction & 0.25 & $2.15^{*}$ & Accept H4 \\
Emphaty $\rightarrow$ Customer Satisfaction & 0.04 & 0.41 & Deny H5 \\
Customer Satisfaction $\rightarrow$ Revisit Interest & 0.72 & $11.92^{*}$ & Accept H6 \\
\hline
\end{tabular}

Based on the results of the hypothesis test in Table 3, it is known that most of the related variables have a significant effect except the responsiveness and empathy variables. The variable that has the greatest influence on satisfaction variables is the reliability variable with a path coefficient value of 0.37 and a calculated value of 2.29 , meaning that reliability has a significant positive effect on satisfaction of 0.37 . Based on these results, it can be concluded that the better the service and dependability of the tour guides, the higher the customer satisfaction. The variables that have the smallest influence on satisfaction variables are the responsiveness and empathy variables with path coefficient values respectively 0.02 and 0.04 and the t-test values are 0.10 and 0.41 respectively, meaning that responsiveness and empathy do not have a significant positive effect on consumer satisfaction.

\subsection{The Effect of Tangibles Variables on Consumer Satisfaction}

The results of hypothesis testing indicate that the tangibles variable has a significant positive effect on customer satisfaction with a path coefficient of 0.26 and a t-test of 2.29 . The results of this study are slightly different from Pratama (2016) which states that tangibles have a positive influence on visitor satisfaction, but the effect is not 
significant enough. The difference is possible because the tourist object that is used as the object of research is a fort in Bengkulu City, which does not present natural beauty as a tourist destination, but rather the history of the place.

\subsection{The Effect of Reliability Variables on Consumer Satisfaction}

The test results show that the reliability variable has a significant positive effect on customer satisfaction with a path coefficient of 0.37 and a t-test of 2.13. This is slightly different from Pratama (2016) research which states that reliability has a positive effect on visitor satisfaction, but the effect is not significant enough. This difference is possible because the location of the fortress is not in a location that requires the reliability of the tour guides. This is different from Saporkren which has a location in the forest and the role of tour guides is very necessary and must be reliable by visitors.

\subsection{The Effect of Responsiveness Variables on Consumer Satisfaction}

The test results show that the responsiveness variable does not have a significant positive effect on customer satisfaction with a path coefficient of 0.02 and a t-test of 0.10 . The results of this study are slightly different from Pratama (2016) which states that responsiveness has a positive and significant effect on visitor satisfaction, the difference is possible due to differences in the capacity of the tourist attraction officers at the fort and at Saporkren.

\subsection{The Effect of Assurance Variable On Consumer Satisfaction}

The test results show that the assurance variable has a significant positive effect on satisfaction with a path coefficient of 0.25 and a t-test of 2.15. The results of this study are consistent with Pratama (2016) which states that assurance has a positive and significant effect on visitor satisfaction,

\subsection{The Effect of Variable Emphaty on Consumer Satisfaction}

The results of hypothesis testing indicate that the emphaty variable does not have a significant positive effect on customer satisfaction with a path coefficient of 0.04 and a t-test of 0.41 . The results of this study are slightly different from Pratama (2016) which states that emphaty has a positive and significant effect on visitor satisfaction, this difference is possible due to the ability of human resources in Saporkren with different fortifications of Marlborough to pay attention to the needs of visitors.

\subsection{The Influence of Consumer Satisfaction Variables on Revisit Interests}

The test results, showed that the variable of customer satisfaction had a significant positive effect on the interest in a repeat visit with a loading factor of 0.72 and a t-test of 11.92 . The results of this study are supported by the Septiawati study (2018) which states that consumer satisfaction has a positive influence on the interest in a return visit.

\subsection{Managerial Implications}

Revisit interest from ecotourism visitors at Saporkren has been proven through this study being influenced by customer satisfaction obtained during a visit. Consumer satisfaction at Saporkren is influenced positively and significantly by tangibles, reliability, and assurance variables. This is in accordance with the theory according to Irawan (2008) which states that visitor satisfaction is influenced by service quality.

\section{a. Tangibles}

Managers need to continue to preserve nature in Saporkren, because physical evidence in the form of natural beauty is one of the main selling points of ecotourism in Saporkren. Managers also need to maintain the condition of existing facilities so that they are always in good condition and ready for use. Managers must also be able to establish good communication with other stakeholders, because not all matters directly or indirectly related can be handled by the manager himself.

\section{b. Reliability}

Organizing activities in the form of capacity building and capability of the officers (tour guides) in Saporkren needs to be done to make the officers always ready and reliable by the visitors. The making of standard operational procedures (SOP) and simulation of SOP applications also need to be done so that the officers are ready to face situations that might occur

\section{c. Assurance}

Conducting training activities for officers is important in order to convince visitors to trust officers. Activities such as character building can be done so that the officers have the ability and soul to serve even better to satisfy 
the visitors.

Based on the results of the study, identified three of the five factors of service quality, namely tangibles, reliability, and assurance affect customer satisfaction in Saporkren. The reliability variable is the most dominant variable than the other variables. Empathy and responsiveness variables have no positive and significant effect on consumer satisfaction at Saporkren. Consumer satisfaction affects the interest of a repeat visit. Tangibles (physical evidence) and assurance (assurance) aspects also need to be considered by management in increasing customer satisfaction which can also affect increased interest in a return visit. The results showed that the management of Saporkren needs to prioritize reliability aspects as a consideration in managerial decision making. Reliability is important because Saporkren's ecotourism conditions in nature really need officers who can be relied on by visitors. The strategy that can be implemented is exploring tourism potential that can be exploited besides birdwatching for tangibles, and training and certifying tour guides in Saporkren for reliability and assurance factors.

Improvements in the aspects of reliability, tangibles, and assurance need to be done to improve customer satisfaction and make visitors have an interest in revisiting Saporkren. If this happens, of course the ecotourism business can provide maximum results for the manager's income, because Saporkren still has a gap between the number of visitors and visitor capacity. With this gap, it indicates that Saporkren still has great potential to get even higher income. Increasing the capacity of Saporkren officers needs to be a priority because the results of the study show that reliability is the most influential factor in customer satisfaction. Suggestions for further research is to conduct research by analyzing the direct influence between tangibles, reliability, responsiveness, assurance, and empathy for the interest in a visit.

\section{Acknowledgments}

Praise the Lord, God Almighty for all His blessings and love, so this scientific work was successfully completed. The title chosen in the study was The Influence of Service Quality to the Consumer Satisfaction and Revisit Interest of Saporkren Ecotourism at Raja Ampat Regency. On this occasion the authors would like to thank Dr. Siti Jahroh, BSc, MSc and Dr. Ir. Kirbrandoko, MSM as the supervisory commission for guidance and motivation. The author's appreciation goes to the head and staff of the West Papua Natural Resources Conservation Agency, the Raja Ampat Regency Government, the coordinator and members of the Raja Ampat Fauna \& Flora International - Indonesia Programme, the leaders and members of the Saporkren Forest Farmers Group, as well as those present in the Focus Group Discussion. Finally, I hope this thesis is useful for those who need it.

\section{References}

Assael H. (2007). Consumer Behaviour. Boston, MA: Thomson-Learning.

Ban, J., \& Ramsaran, R. R. (2016). An exploratory examination of service quality attributes in the ecotourism industry. Journal of Travel \& Tourism Marketing, 34(1), 132-148. https://doi.org/10.1080/10548408.2016.1141155.

Bebko, C. P. (2000). Service intangibility and its impact on consumer expectations of service quality. Journal of Service Marketing, 14(1), 9-26.

Irawan, H. (2008). Sepuluh Prinsip Kepuasan Pelanggan. Jakarta, ID: Elex Media Komputindo.

Kotler, P. (2002). Manajemen Pemasaran. Jakarta, ID: Prehallindo.

Kotler, P., \& Armstrong, G. (2004). Principles of Marketing (10th ed.). New Jersey, NJ: Pearson Prentice.

Nikijuluw, V. P. H., Papilaya, R. L., \& Boli, P. (2017). Daya Dukung Pariwisata Berkelanjutan Raja Ampat. Jakarta, ID: Conservation International Indonesia.

Nuraeni, B. S. (2014). Analisis faktor-faktor yang mempengaruhi minat kunjung ulang wisatawan Museum Ranggawarsita Semarang. Jurnal Bisnis Strategi, 23(1), 1-20. https://doi.org/10.14710/jbs.23.1.1-20

Parasuraman, A., Zeithaml V. A., \& Berry, L. L. (1988). SERVQUAL: a multiple-item scale for measuring consumer perceptions of service quality. Journal of Retailing, 64(1), 12-37.

Pratama, H. F. (2016). Pengaruh kualitas pelayanan petugas terhadap kepuasan pengunjung di objek wisata sejarah Benteng Marlborough di Kota Bengkulu. Ekombis Review, 4(1), 24-35. https://doi.org/10.37676/ekombis.v4i1.152

Septiawati, R. (2018). Pengaruh kualitas pelayanan terhadap niat pembelian ulang produk dengan kepuasan pelanggan sebagai variabel mediasi. (Unpublished master's thesis). Universitas Lampung, Bandar 
Lampung, Indonesia.

Sinaga, E. K., \& Utomo, B. S. (2014). Kualitas pelayanan pemanduan ekowisata di Taman Nasional Tanjung Putting Kabupaten Kotawaringin Barat Kalimantan Tengah. Jurnal Manajemen Resort \& Leisure, 11(1), 7-23.

Tjiptono, F. (2008). Strategi Pemasaran. Yogyakarta, ID: Andi.

Wiratno. (2012). Tersesat di Jalan yang Benar Seribu Hari Mengelola Leuser. Jakarta, ID: Perpustakaan Nasional.

Yeblo, M., Kiroh, H. J., Nangoy, M. J., \& Rawung, V. R. W. (2015). Studi beberapa faktor pendukung pengembangan ekowisata berbasis fauna endemik di Hutan Sawinggrai Kecamatan Miosmansar Kabupaten Kepulauan Raja Ampat Propinsi Papua Barat. Jurnal Zootek, 35(2), 210-224.

\section{Copyrights}

Copyright for this article is retained by the author(s), with first publication rights granted to the journal.

This is an open-access article distributed under the terms and conditions of the Creative Commons Attribution license (http://creativecommons.org/licenses/by/4.0/). 